\title{
ストーカとオイルバーナ
}

\section{I 序言}

占上そ熱源を使用寸る生産工栄で生産原価て対する然 料費の割合がどんな額になるかに重要な関心がよせられ ない列はない。醉造工業においてもまた然りで, 殻類の 蒸し上げから温湯による洗罎作業にいたるまで原価の数 \%から多ければ数 10\%を燃料費が占めることを考えれ ば，然料の選定示よで然烧設備の改善にはさらに一層の 検討が加えられてよいとおも5。

戦徯 10 数年来, 蒸気発生設備としてのボイラの進歩 はまことに目筧むしいすのがある。ことに中小形ボイラ は主として西ドイッおよびアメリカの影響をうけて急激 な発澾を見せ, 形式, 機能の改良はもとより効率の向上 亿暴常な発展を逐げて近代設備としての使命を完全に果 しつつるる。

これまで蒸気ボイラとい光ば一般には立午，コルニッ シュ年, ランカシャ缶, 横置多管缶, 鋳鉄製セクショナ ル缶, ケワニー型缶, 小形水管缶等が主として中小工場 等で生産用または䁔房用として用いられてきた。また特 に醸督の専用設備として和崟が愛用されている。これら の外に新らしいボイシとして最近特に多く使われるよう になってきたもの浊いわるマルチパスボイラである。 このマルチパスボイジは梮筒ボイラの一種で, 形の上で はコルニッシニ形とケワニー形とを組合せたようなもの だがボイラ内にお方就ガスの連行を 2 パスなたは 3 パ スとし，秀た時に法4 ススの構造としている。そのため 高温ガスによる熱の缶跬への移動は非常に効果的で, ボ イラ效率がこれまだの小形ボイラに見られない高い数值 を示している。 H K ボイラ，MPボイラ，F Tボイラ等 がこれである。

ボイラ效率の点から見ればマルチパスボイラは $80 \%$ 以上を確保し，好条件の下では $85 \%$ 以上の高効率定示し て大形水管缶に勝るとも少らない好成績を招さめている。

*株式会社 大東工菜所

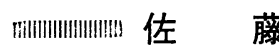

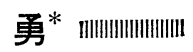

新らしい工場設備としてのボイラの選定には重大な関心 が扗われなければならない。

さてこの蒸気ボイラの性能を完全に発揮するためには 言うまでもなく燃焼設備を近代化させる必要がある。生 産規模の大小にかかわらず，ボイラの性能を最も能率よ く使用するため然焼方式が合理的で市るか否かを充分に 検討し思い切った改良が加えられるべきである。然焼方 法を人力にたよる如きはすでに論外で，新しい設備では 如何にして機械焚きを完全汇行らかにある。ここには石 炭および重油燃焼の新しい万法の概略を述べたいと思う。

\section{III石炭焚きストーカ}

A ストーカ焚き：石炭然焼の機械的な方法としては ストーカ焚きおよび微粉炭焚きの方法があるが微粉炭法 は主として大形設備の発電所ボイラ等に供され工場生産 用としては不適当である。

ストーカ焚きは手焚きに比較して労力の節約ができる こと, ボイラを一定負荷状態に保持しやすいこと，然焼 効率がよく煤煙の発生も少ないので, 工場設備として喜 ばれているが，その方法には次の 3 種がある。

上达式ストーカ…石炭を上から供給し, 通風以逆に下 から行な 5 。

下込式ストーカ‥下から石炭を供給し, 通風枕これと 並行に行なら。

横込式ストーカ…石炭を横から供給し, 通風はこれと 直角に下から行なら。

この5ち然焼効率も他に劣らず，取扱も簡単で設備費 が最も低廉で岕る点で下込ストーカ汇勝るものはない。

B 下込ストーカ：最近の下込式ストーカはボイラの 進歩に伴ってそれに適合するすべての形式のものがつく られるようになって来た。これは隇速装置で回転される スクリューコンベヤによりホッパの中の石炭をレトルト 内部から上に押し出し谪当な炭畨をつくってこれる燃焼 させるもので心る。燃焼用空気は減速装置に直結される 


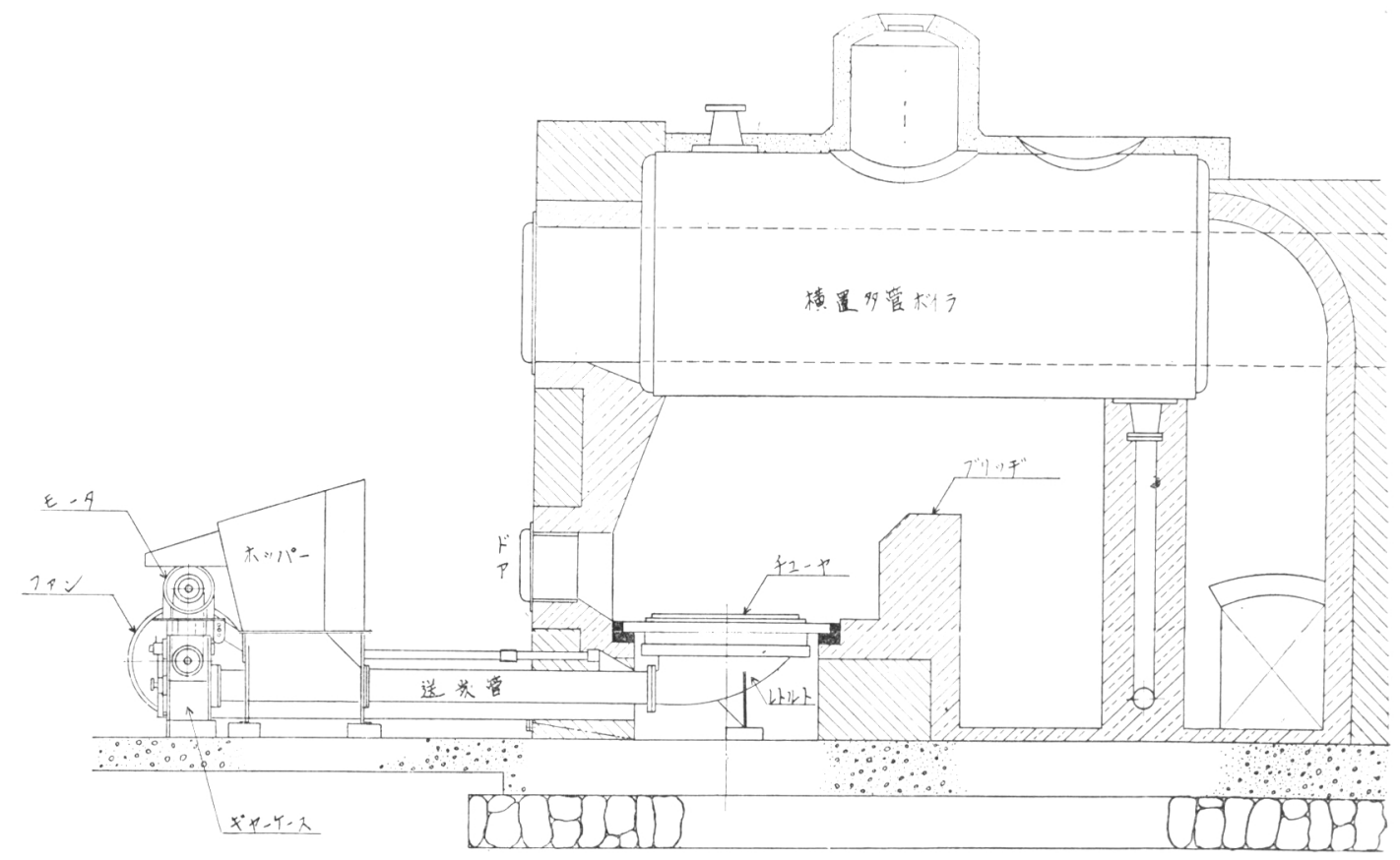

第 1 図下込式 ス卜 - 力

かまたは単独式に設けられたファンによって一且レトル ト外周の空気空に沶くられ, 羽口から吹き込采れて炭層 の間老通り表面に出つつ石炭の乾燥, 乾溜, 還元, 酸化 の行程を経て然焼をつづるものである。第 1 図に普通 型のストーカの外観を示した。

下达式ストーカの能力は小形のもので然焼量每時 $5 \mathrm{~kg}$ から最大 $750 \mathrm{~kg}$ まで各種に分けられこれに付属する送風 用ファンは供給した石炭を完全に燃焼するに充分な容量

第 1 表 DIF ストーカ能力表

\begin{tabular}{|c|c|c|c|c|c|c|c|c|c|c|}
\hline \multirow{3}{*}{ 形式番号 } & \multicolumn{3}{|c|}{ 送炭 } & 量 & $\mathrm{kg}$ & $/ \mathrm{h}$ & & \multirow{3}{*}{$\begin{array}{l}\varepsilon- \\
\text { タ- } \\
\mathrm{kW}\end{array}$} & \multicolumn{2}{|c|}{ 送風 機 } \\
\hline & \multicolumn{3}{|c|}{3 段式 } & \multicolumn{4}{|c|}{4 段 式 } & & \multirow{2}{*}{$\begin{array}{ll}\text { 風 } & \text { 压 } \\
\mathrm{mmmAq}\end{array}$} & \multirow{2}{*}{$\begin{array}{l}\text { 風 } \\
\mathrm{m}^{3} / \mathrm{g} \\
\quad \mathrm{min} \\
\end{array}$} \\
\hline & 1 & 2 & 3 & 1 & 2 & 3 & 4 & & & \\
\hline No. 40 & 6 & 13 & 20 & - & - & - & - & 0.2 & 20 & 4 \\
\hline No. 60 & 10 & 20 & 30 & - & - & - & - & 0.4 & 20 & 6 \\
\hline No. 90 & 14 & 27 & 40 & - & - & - & - & 0.4 & 20 & 8 \\
\hline No. 115 & 17 & 34 & 50 & - & - & - & - & 0.4 & 20 & 10 \\
\hline No. 160 & 20 & 40 & 70 & 30 & 40 & 60 & 70 & 0.75 & 20 & 12 \\
\hline No. 220 & 30 & 70 & 100 & 40 & 60 & 80 & 100 & 0.75 & 25 & 16 \\
\hline No. 350 & 50 & 100 & 150 & 55 & 80 & 115 & 150 & 1.5 & 25 & 23 \\
\hline No. 420 & 60 & 130 & 200 & 75 & 110 & 155 & 200 & 1.5 & 25 & 31 \\
\hline No. 550 & 90 & 170 & 250 & 100 & 140 & 200 & 250 & 2. 2 & 25 & 40 \\
\hline No. 650 & 100 & 200 & 300 & 120 & 170 & 240 & 300 & 2.2 & 30 & 48 \\
\hline No. 850 & 140 & 270 & 400 & 160 & 230 & 320 & 400 & 3. 7 & 30 & 64 \\
\hline No. 1000 & 150 & 300 & 450 & 175 & 260 & 360 & 450 & 3.7 & 30 & 72 \\
\hline No. 1200 & 175 & 350 & 500 & 190 & 290 & 400 & 500 & $\begin{array}{l}1.5 \\
3.7\end{array}$ & 30 & 80 \\
\hline No. 1450 & 200 & 400 & 600 & 220 & 340 & 470 & 600 & $\begin{array}{l}1.5 \\
5.5\end{array}$ & 30 & 94 \\
\hline No. 1600 & 250 & 500 & 750 & 280 & 430 & 600 & 750 & $\begin{array}{l}1.5 \\
5.5\end{array}$ & 30 & 120 \\
\hline
\end{tabular}

をもっている。秃た給炭量の切換方式も 3 段，4段をた は6 段でな特使用者の希望で無段変速も可能である。第 1 表に DIF 下込式ストーカの標準能力表起示した。

下込式ストーカはさきにも述ベたよに各種のボイラ に专わせて種々の形式につくられている。立形ボイラま たは円形ファーネスのよ弓に燃焼室が円い形をしたもの には火床部分を円形につくった V形ストーカや，炉筒ボ イラの場合には思い切った低床方式をとってこれまで手 梦きでも然焼室高さを充分にとれないため石炭の完全然 焼がなし得なかったものを根本的に改造して高い缶効辩 走出せるよらになった LC 形スト一カがある。また $4,000 \mathrm{kcal} / \mathrm{kg}$ 程度の比較的低発熱量の石炭燃焼用とし て有効火格子面積を大きくとった ST 形ストーカがあり， さらにダンプグレートにより燃焼庅をハンドル操作で火 格子の下部に落下せしめ除灰用スクリューコンベヤを動 かして午外に排出させる構造のストーカもある。

特殊の形式の\&のとしてはビンフィード式ストーカと いって石炭ホッパを用いずに唄炭庫から直接ボイラに送 炭して焚焼するものも岕り, ニニバーサル形ストーカで は石炭ホッパまなは唄炭庫から石炭を運びこれを途中で 方向変換して任意の向きに送炭がでさる。ニニパーサル 形は缶前が狭险で操作困難の場合に使用して便利である。 コークス用ストーカは下込式ストーカの特例で㷊煙を特 に嫌うところに使われている。 


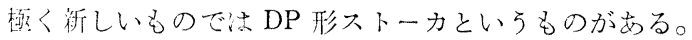
これ沈スクリューコンベヤを用いずと油压機構でピスト ンこ往復喠動を与えこれによって送炭用プッシュバーを 作動してプッシュブロックにより炭層をつくる形式のも ので, 总炭鼠が無段階調整できるばかりでなく炭層形成 が幅圤まく長くできるので大形ボイラの多量送炭に適し

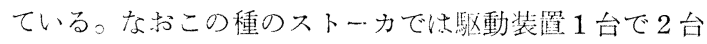
又汭台以上のストーカの渾転が可能である。

石炭焚きの場合然焼公をどのような大きさにつくるべ きか心手焚き，機械焚きともに重要な事項である。

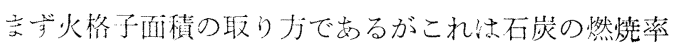
こ天り算定され, 然焼摔估不岑の種類, 燃焼力法扣上び 通風のしかたによって置る。すなわち

$$
\text { 火格子面積 } \mathrm{m}^{2}=\text { 石炭然烧量 } \mathrm{kg} / \mathrm{h}
$$

下运ストーカの場合の然焼率仕通常 $200 \sim 300 \mathrm{~kg} / \mathrm{m}^{2} \mathrm{~h}$ と岂れているがもしろ $200 \mathrm{~kg} / \mathrm{m}^{2} \mathrm{~h}$ 位を限界としたおが よされらに思われる。

つぎに然焙空 $1 \mathrm{~m}^{3}$ 当门の発熱星を火炉熱発生率とい

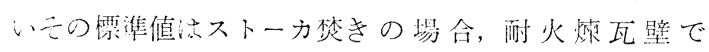
$150,000 \sim 300,000 \mathrm{kcal} / \mathrm{m}^{3} \mathrm{~h}$, 水冷壁で $200,000 \sim 350,000$

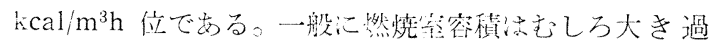
ぎる位ことるオが舆難である。

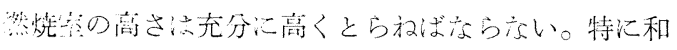

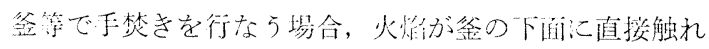

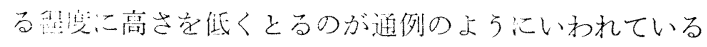

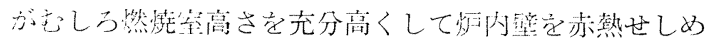

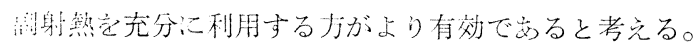

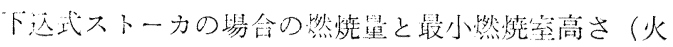
简子上）の関係走示せば次の如くである。

\begin{tabular}{|c|c|}
\hline 酒洔然辇量 & $20 \mathrm{~kg} \cdots \cdots \quad 600 \mathrm{~m} / \mathrm{m}$ \\
\hline$" \prime$ & $30 \mathrm{~kg} \cdots \cdots 620 \mathrm{~m} / \mathrm{m}$ \\
\hline " & $50 \mathrm{~kg} \cdots \cdots \quad 700 \mathrm{~m} / \mathrm{m}$ \\
\hline " & $100 \mathrm{~kg} \ldots \ldots 760 \mathrm{~m} / \mathrm{m}$ \\
\hline " & $150 \mathrm{~kg} \ldots \ldots 900 \mathrm{~m} / \mathrm{m}$ \\
\hline " & $250 \mathrm{~kg} \cdots \cdots 1000 \mathrm{~m} / \mathrm{m}$ \\
\hline " & $400 \mathrm{~kg} \cdots \cdots 1250 \mathrm{~m} / \mathrm{m}$ \\
\hline " & $500 \mathrm{~kg} \cdots \cdots 1500 \mathrm{~m} / \mathrm{n}$ \\
\hline
\end{tabular}

们荻の然焼用空父蚛理論上， $1 \mathrm{~kg}$ につき $6 \sim 7 \mathrm{Nm}^{3}$

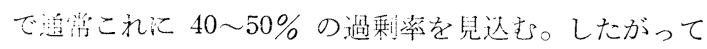

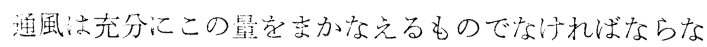
い。通風江任自通風, 押达通風, 誘引逝風, 平衡通風等 の方法がある。

自然通風は煙突の作用で通気力を出すもので, 高さ拉 上で直径が通気力を支配一るが都市では最低の煙突高さ が規定されているので概して細く高くきめられる。ケン
トの式が我国で最も多く，煙突容量をきめる場合に用い られている。

自然通風のみで值氮が不充分な場合に押込通風の方 式が採られる。これ怡炭層抵抗の大きい場合, 煙道が長 く抵抗が大なる場合，煙道途中に熱回收装置を持った場 合等に用いられる。

誘引通風休洷突の下部又住煙道の途中に送風機を置い て炉内から然焼ガスを誘引して煙突に放出せしめるもの で煙突の高さが低くても充分通父補助の目的を達するこ とができる。

平衡通風仗押达送風をたは誘引送風のみで通風壳行な 弓時炉内の压力が著しく大気圧と異る場合にこれをバラ ンスさせるために両者学並用してこれをわずかにマイナ スに保持する方法である。

以上各種送風の方法柱使用するボイラの種類により適 宜選定され，押达送風機扣よび諉引送風機の能力はすべ て然焼の条件によって左右されるので, 装置の決定には それぞれのメーカーとくわしく打会せする必要が宓る。

\section{III オイルバーナ}

ここ数年来重油の価格が石炭に比べて廉くなり㗭念さ れてい輸入困難执よび消費規正法も祘い执い緩和される におよんで, 然焼設備注次第にストーカからオイルバー ナへ転換される傾问が強くなってきた。

い重油の利点と欠点を列学するとつぎのようにな る。

a. 利 点 着火が簡単で発熱埋が高く燃焼效彎がよ い。品質が大体一定している。負荷变動こ対し渙応 性が大きく調整が簡笚である。運搬貯蔵に便利であ る。煤煙が少なく，灰の取扱の面倒さがない。自動 制御が簡举に行なえる。

b . 欠 点 重油は外国からの輸入に頼らねばならぬ。 高温燃接のため炉内局部加蓺の傾向がある。取扱を 䛊ると火災, 逆火等の事故の危険性がある。硫黄に 上る應蝕が不炭より激しい。

\section{A 重油の燃焼条件 :}

重油燃焼の第1の条件は重油恀そのままの形では然し 難いからこれをバーナによって微細な顂霧とすることで ある。それに休重油にポンプで压力を与光小さな孔から 賴射する方法, 空気女るい快蒸気で重油を噴射するもの, また位高速回転する霧化筒の内面化重油を和くって遠心 力で微細に霧化する方法等がある。何れも噴霧はごく微 細なもので直経 $10 \mu \sim 100 \mu$ 程度が良好な状態とされ ている。務化の方法によって組いものと粗いものとが 混合する場合もあるが平均䊉経が小さいものよりも粗大 粒経のものが混合しないバーナが優良なバーナである。 
重油燃焼の第 2 の条件は噴霧の形または火焰の形が然 焼室の形とよく適合していることである。燃焼室形状が 細く長大形であるのに火惂が幅広く短いと燃旗室の左右 両壁に火焰が打突かり噴霧が未燃焼のまま炭化して堆積 し効率を低下させる基となる。逆に水管缶などのように 然焼室が広い場合に幅の狭い長焰のバーナでは順調な蒸 気発生を期待することはできない。

第 3 の条件は燃焼空気が適量なことである。これは石 炭の場合と同様理論空気量に対する空気過㔞率が最小で しかも完全然焼することが理想である。空気量が不足で あれば末燃焼を执こして煙の基となり，また多過ぎれば 燃焼室内を泠却して蒸気発生を妨げる。一般に重油燃焼 の理論空気量は $11 \sim 11.5 \mathrm{Nm}^{3} / \mathrm{kg}$ とされ, 空気過剩率

\section{も $1.2 \sim 1.4$ で石炭にくらべてやや少ない。}

第 4 の条件は重油の噴霧と送入空気がよく混合して然 焼を無䭾なく完全に行なうことである。空気送入の方法 には煙突による自然流入, 送風機による强制通風, 誘引 遥風，平衡通風等があるがどれが最も適切であるかはボ イラの構造, 形式, 性能によって異る。何れにしても送 入空気と然焼ガスとが共存のま屯ボイラ内部や煙道を通 過すること汻されず完全混合が必要である。

燃焼室の負荷率は石炎の場合とほぼ等しい位である。 すなわら通常の状態で $350,000 \mathrm{kcal} / \mathrm{m}^{3} \mathrm{~h}$ 以下位が普通 で台る。

最江重油焚きボイラで加圧然坃を行ない炉内ドラフト をプラスの状態で運転する傾向が次第に强くなってき た。この埸命の負荷率は上記と買りずっと高い数值を示 して $500,000 \sim 1,000,000 \mathrm{kcal} / \mathrm{m}^{3} \mathrm{~h}$ に㧍よぶこともある。

\section{B 各種バーナとその特徵：}

すでに述べたようにオイルバーナは質露の様式によっ てそれぞれに分類される。

油压式バーナは重油に 8～ $20 \mathrm{~kg} / \mathrm{cm}^{2}$ の压力を与え， 小孔から高速で賁射して噴霧とするものて， 㞍油式と非 㞍油式とが女る。㞍油式では返送油管をそなえて然焼に つかった余分の油をタンクに展すようになっているが非 㞍油式ていこの返送油管を持たない。油星式バーナは燃 油量の調節範囲がせをくをた重油の糊度による油量およ び然焼状態の変化が大きい。小容量のものではノズが つ壱り易くよくないが大容量のものは良好な然䐠を行な うので負荷変動の少ない発電所ボイラや大形船艋用ボイ ラに遁与る。

低䚾空気噴霧式バーナは $0.05 \sim 0.25 \mathrm{~kg} / \mathrm{cm}^{2}$ の空気压 を重油に与え噴射するもので, 構造簡単で油量範国も割 合に大きく火焰は角度中程度, 長さは短く, 小形の加熱 炉に適する。

高王気流噴霧式バーナは蒸気の圧力または高压の空気
を利用して霧化するもので重油との混合の方法により内 部混合式バーナと外部混合式バーナがある。取扱が簡単 で然焼も悪くはないが高圧気流を用いるため騷音を発す るのが欠点である。火焰は狭角長焰で平炉, 連続加熱则 等に使用される。

回転霧化式バーナは高速回転する霧化简に重油を供給 しこれを遠心力で細粒とし，霧化简と同軸に設けられた ブロワーから旋回空気をおくって更に噴霧を微細化させ る方式のバーナである。焰の角度はある程度広く長く も, 狭く短くも調節ができるので負荷変動の多い中小形 の各種のボイラに適している。

\section{C ロータリバーナ :}

ロータリバーナはさきに述べた回転霧化式バーナで A．B．Cの各種重油が然焼でき噴霧は特に微細になるよ らに特別な考慮が払われている。一例として DIF ロー タリーバーナの断面を第 2 図に示寸。

バーナの主要部はギヤケース, 主朝, サクションポン プ,メータリングポンプ, オイルリザーパ, ファン, 霧 化筒, エアノズル，オイルヒータ，2 孔式ヒンヂより成 る。オイルリザーバはアルミ鍮物製でその中にヒーター とポンプそ内蔵している。サクションポンプはギヤポン プで主軸から回転をとるウォームホイールに直結され， サービスタンクからオイルを四い上げてリザーパの中に 常にオイルを充沑させて置く。メータリングホンブはオ イルを回転中のアトマイジングカップ（霧化筒）へ正確 におくるためのピストン形ポンプで数個のシリンダから 成り順次にストロークして油の吸入送油を繰り返す。油 量は簡単なカム装置でピストンストロークを変它ること により調節できる。フアンによって供給される一次空気 はファンから出てェアノズルを通り然㸁宝内に噴出する。 一次空気量はその目的が大部分オイルの蓩化のみを目的 とするので，燃焼に必要全空気量の 15～20\% 位で他 はすベて二次空気から得られる。索たエアノジルには火 焰の形を燃焼室の形に㟒わたて良好な然焼を行わせるた

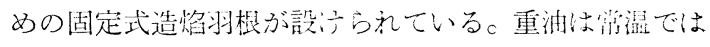
粘度が高いので，ヒーターで加熱し数度をレッドウッド No. 1 で 100〜120 位に下!゙゙てやる必要がある。DIF バ ーナでは電気ヒーターがケイルリザーバの中に内蔵され ている。

第 2 表に DIF ロータリーバーナの能力表走亦。 また第 3 図に実際に、ルチバス命イラに取りつけた口 ータリーバーナを写真で示方。

第 4 㘠にロータリーバーナの眨管図の一例を示し説明 は省略する。

\section{D ロータリーバーナの自動制御：}

オイルバーナは石炭焚きに比べて自動コントロールが 


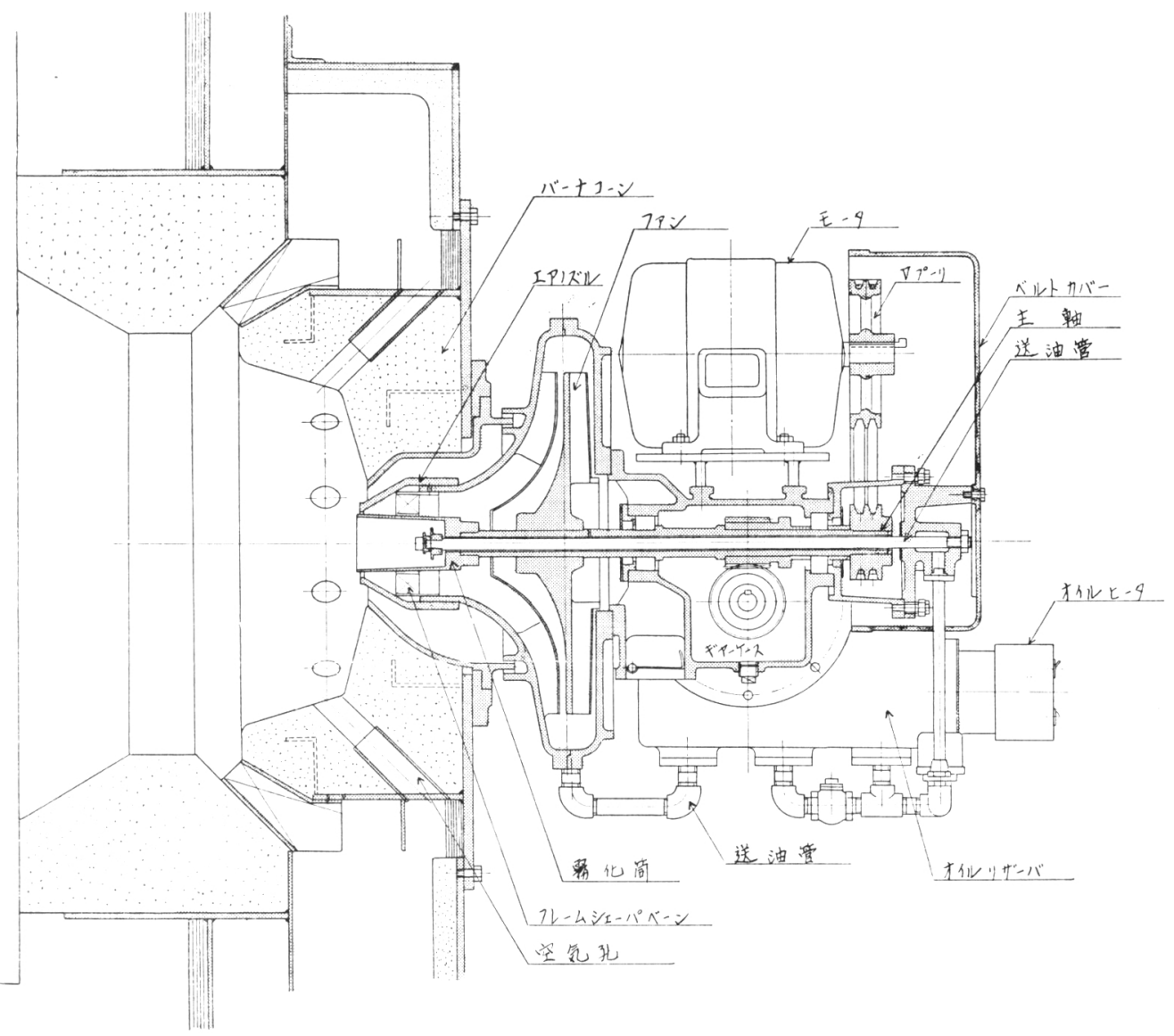

第2図口-タリオイルパーナ

第 2 表 DIF ロータリーバーナ能力表

\begin{tabular}{|c|c|c|c|c|c|}
\hline 式 & $\begin{array}{c}\text { モ-多 } \\
\mathrm{kW}\end{array}$ & 燃侪 量 & $\begin{array}{l}\text { 七-タ- } \\
\text { 容量 } \mathrm{kW}\end{array}$ & $\begin{array}{r}\text { 発熱量 } \times 100 \\
\text { kcal/h }\end{array}$ & $\begin{array}{l}\text { 相当石㟶 } \\
\text { 量 } \mathrm{kg} / \mathrm{h}\end{array}$ \\
\hline DR-9 & 0.4 & $15 \sim 35$ & 1.2 & 255 & 95 \\
\hline DR-16 & 0.75 & $22 \sim 60$ & 2.0 & 450 & 165 \\
\hline DR -25 & 0.75 & $32 \sim 95$ & 3.2 & 712 & 264 \\
\hline DR-3j̄ & 1.5 & $42 \sim 135$ & 4.5 & 1020 & 375 \\
\hline DR-50 & 1.5 & $53 \sim 190$ & 5.5 & 1425 & 530 \\
\hline DR-60 & 1.5 & $63 \sim 230$ & 6.5 & 1725 & 640 \\
\hline DR-76 & 2.2 & $76 \sim 290$ & 8.0 & 2175 & 800 \\
\hline DR-100 & 3.7 & $95 \sim 380$ & 10.0 & 2850 & 1050 \\
\hline DR-125 & 3.7 & $120 \sim 480$ & 12.5 & 3600 & 1330 \\
\hline DR-165 & 5.5 & $160 \sim 630$ & 16.5 & 4725 & 1750 \\
\hline
\end{tabular}

やり易いのでこの点でも近代設備としての価值をそなえ ている。最近てはバーナは手動運転を行ならことはきわ めて稀で涪とんど大部分は半自動または全自動運転で用 いられる。ここに半自動とは着火のみ手動で他はすべて 自動のものを言い，着火も含めてすべて自動を行うもの を全自動と言 万。

自動制御方式には油圧を利用したもの，空気圧を利用 したもの, 電気的作動を行うもの等種々女るが, 機能の 完全発揮はもちろ九, 構造も簡単, 故障も少なく, 価格
も廉い点で一般の 中小形ボイラ用と 乙ては電気的方式 が最も好適と思わ れる。以下簡単に ロータリバーナの 場合についてこれ を述べよ 5 。

a. 着火コント ロール

ロータリーパー ナの着火は電気ガ ス一着火または電 気一軽油着火の方 がとられる。電気 ガス法では都市ガ ス又はプロパンガ

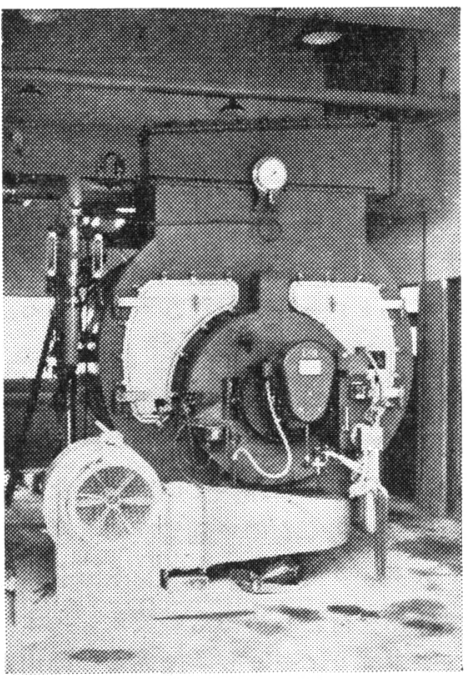

第3図、ルチパスボイラと口 ータリーバーナ

スが用いられ電気スパークでガスに一且着火した後メ一 ンパルブを開いて重油に点火する。ガス着火のためのス 


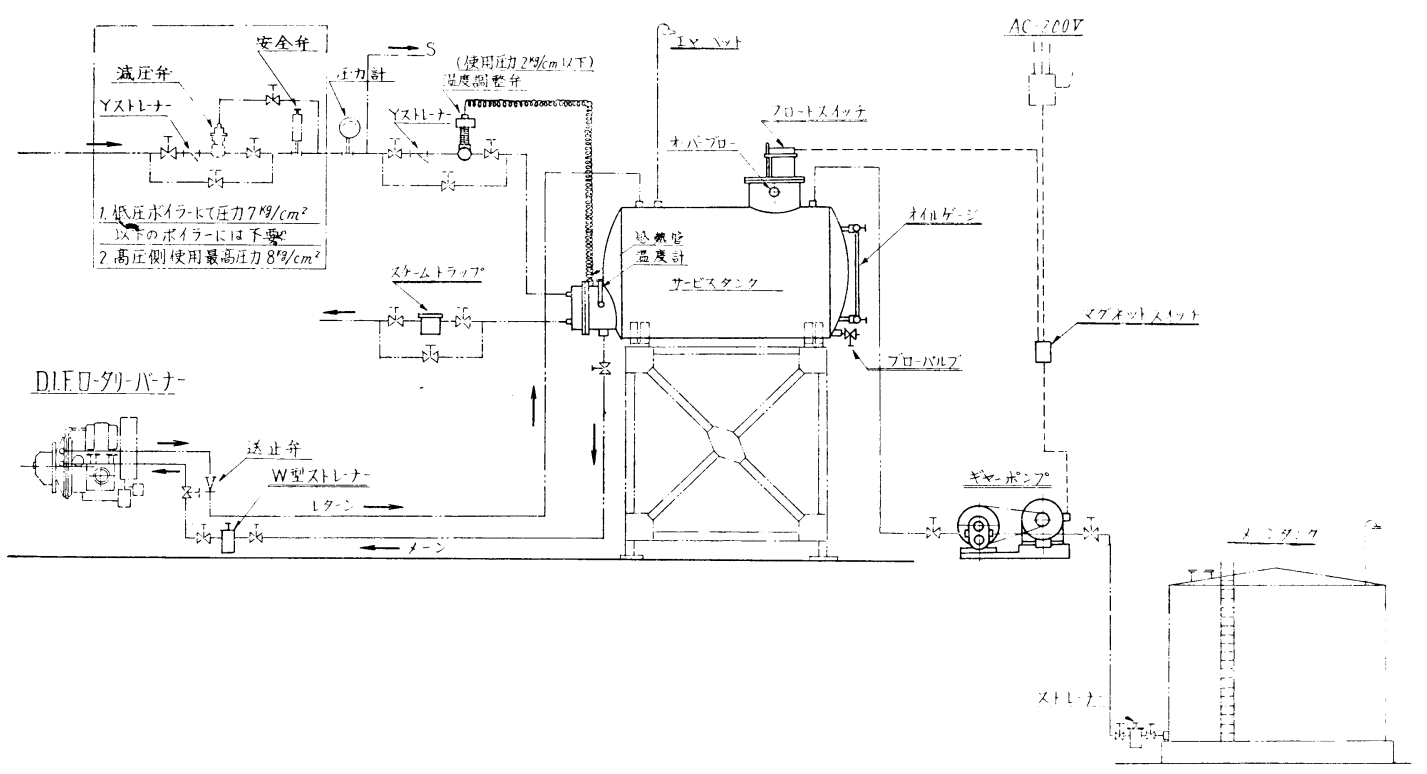

第4図口ータリバーナ配管図

パークの電圧に $6000 \mathrm{~V} \sim 7000 \mathrm{~V}$ である。なた電気一軽 油法で经小形ガンタイプバーナを用い軽油をノズルチッ ブから噴射してこれにスパークで着火せしめ次に重油に 点火する。この埸合の電压忋 $9,000 \mathrm{~V} \sim 12,000 \mathrm{~V}$ である。

b . 燃焼コントロール

これはボイラの負荷に応じてバーナの然焼状態をコン トロールするもので次の 3 種類がある。オン・オフ法で は負荷に応じてバーナの運転交たは停止を行ならもので その作動はボイラの圧力スイッチまたは温度スイッチが 行なら。ハイローフレーム法ではレバー操作により二点 位置モーターのハイの位置或はローの位置で然焼を行な わしめるものである。比例制御方式では作動コントロー ルスイッチによりボイラの負荷変動に応じてモヂュレー ティングモーターで比例的に油量および一次, 二次空気 のコントロールを行ならものである。

c. 安全コントロール

バーナの安全装置は起動時に万が一適確に着火しない 時これを検出して然焼室への送油を停止したりあるいは 運転中何等かの原因で焰が消えた時バーナを停めて事故 を未然に防ぐもので通常次の 3 種がある。

スタックセーフティコントロール㖶道のガスの温度 で作動を行わしめるものでオン・オフ制御に用いられる。

光電管タイマリレーは光電管検出器を用いるものでフ レームアイ又はスキャナーとも呼ばれ焰からの光線を検 出してリレーの作動江用いられる。バーナのスタート時 不着火の場合検出の時間的おくれは $3 \sim 6$ 秒である。

光電管フレームデテクターはフレームロッドと呼ばれ

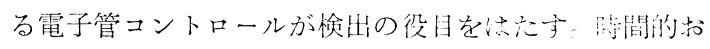
くれ络運転中で $2 \sim 5$ 秒，スタート時で 0 览てるる

d. 作動コントロール

これは犆然烧用空氛のドラフトコントロールを行な5 るの, 㖶道ドラフトコントロールを行なうるのが等るる。 e . 低水位コントロール

ボイラ給水を目動的こコントロールし高るい:繁城装

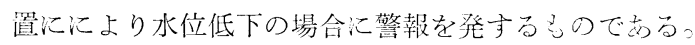

以上が通常用いられる自動制御の人贾で，ホイラの管 量, バーナの形式によって上述のものをそれぞれ組合せ て用いる。

一例として第 5 図汅光電管比例制御方式の系繶闵走示 寸。それぞの部品名称は図中に示した通りである。

1. まず隼備作動としてメーンスイッチ KS, ヒーター スイッチ及び電源スイッチ SWを投入する。次に自動 スイッチ $\mathrm{SW}_{2}$ を入れると安全リレーの電子管が加熱 され始める。約 10 秒経た後運転スイッチ SW 入れ るとパイロットガスバルブが開きガスが出る。同洔に イグニショントランスが励磁されガスに看火する。

2. ついでマグネットスイッチ $\mathrm{Mg} \cdot \mathrm{SW}$ が励磁されモ ーターMが回転を始める。さらに晕延リレーの作動で 約 5 秒後にオイルバルブが開き油が責射して然焼を始 める。

3. 同時にリレー $\mathrm{R}_{2}$ が励磁されコントロールモーター のアームが上り油量を增加しつつ然焼を継続する。

4. 安全リレーがその焰を検出してイグニションを切り ガスバルブを閉じてパイロットバーナを消す。重油はそ 


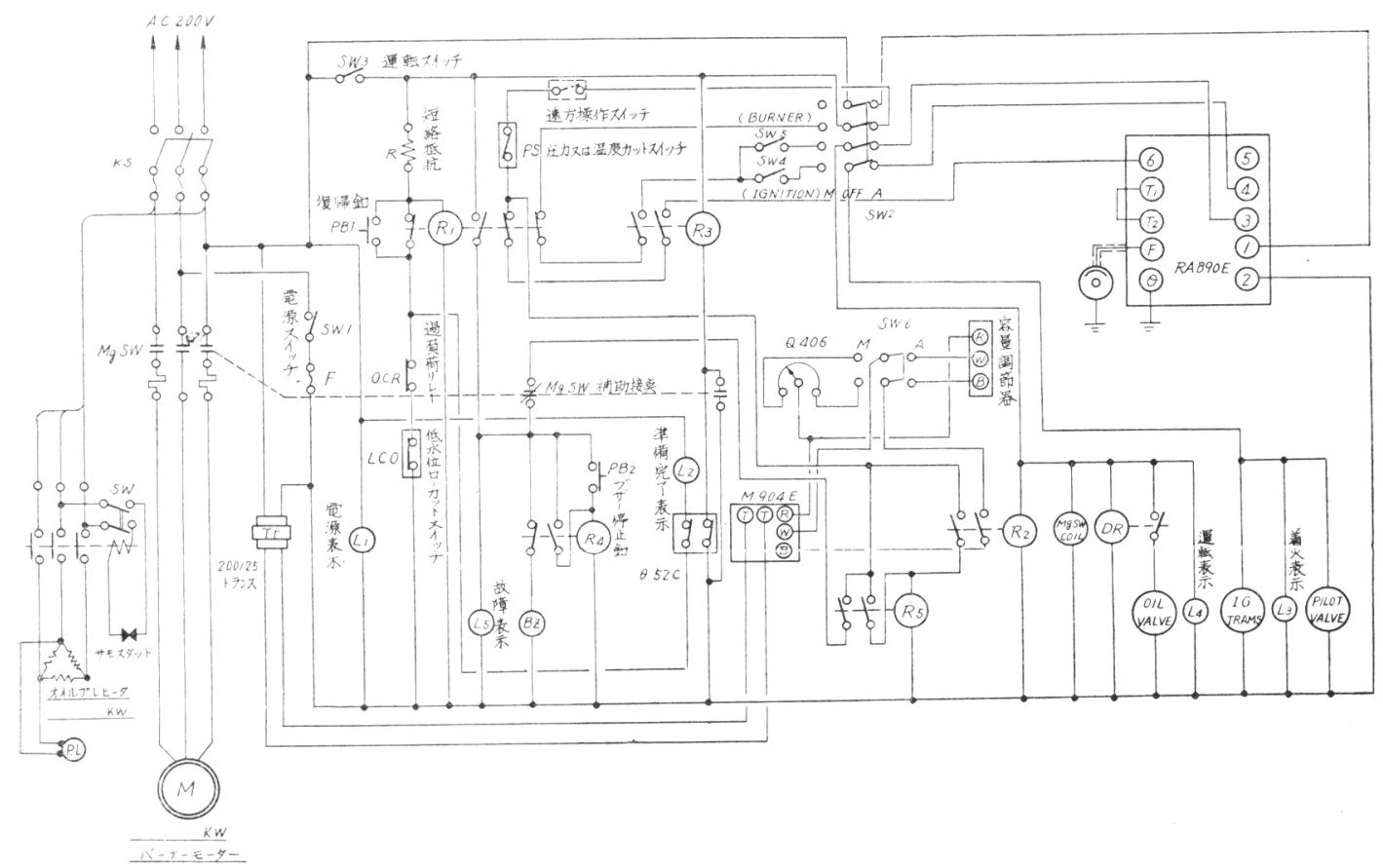

第5図光電管比例制御方式の系統図

のまま燃焼をつつゔる。

5. もしもパイロットパーナが消えた後に焰が消えると 光電管が感知して再びパイロッバーナが働き, セーフ ティスイッチが切れるまで約 30 秒間つづける。

6. バーナ然焼中の油量の制御は容量調節器が行な5。 これはボイラの压力または温度により負荷に応じで作 動しこの指示によってコントロールモーターのアーム が油量を增減させて圧力または温度を一定に保 持する。

7. 容量調節器の七ットされた压力又は温度を越 えるとスイッチ PS が衝きバーナの運転をとめ る。PS が復帰すると安全りレーが働き始動状 態と同じ動作で自動運転を始める。

8. ボイラの缶水が最低水位以下になるとスイッ チ LCO が働きバーナを止め警報ブザーを鳴ら す。この場合給水をして基準水位汇達しても復 帰ボタン $\mathrm{PB}_{1}$ を押すれで芯バーナは運転を始 めない。

9. バーナモーターに過電流が流机た場合は過負 荷リレーOCR が働いてバーナを停め, 警報ブ ザーを鳴らす。この場合も復帰レバーを押すま で络過負荷の原因を取り除いてもパーナは再ス タートしない。

10. バーナ停止の時は $\mathrm{SW}_{3}$ を切りバーナを停 第 57 巻 第 8 号
め、コントロールモーターのアームが下降し終ってか ら電源スイッチを切る。

E 重油用ガンタイプバーナ：

ガンタイプバーナ浪灯油又は軽油専焼用バーナとして 主に小形ボイラや小形熱風炉等に使用されるの久で僅か に特別な例としてオイルヒーター拉よびパーナコーンを 娇用してA重油ぶ梦ける程度であった。元来ガンタイプ

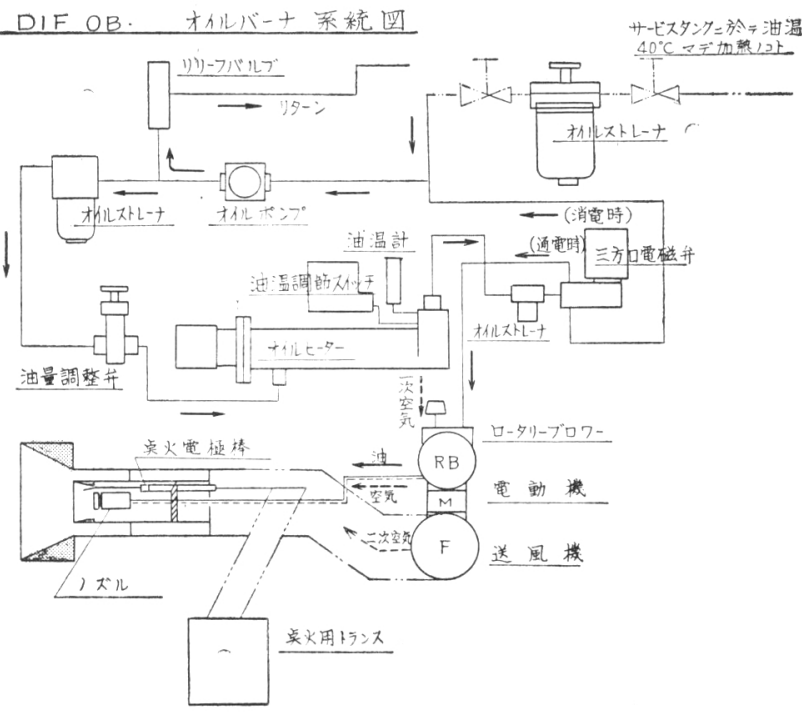

第 6 図 ガンタイプ重油焚バーナ系統図 


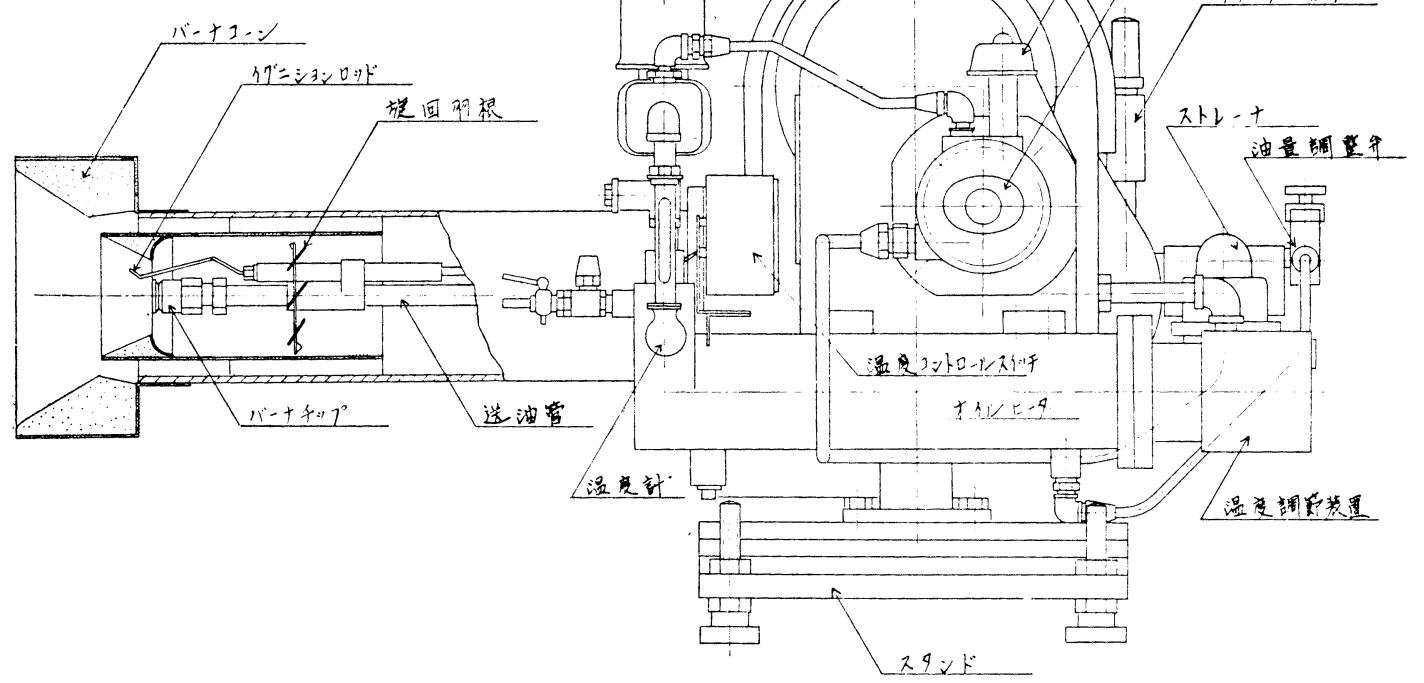

第 7 図 ガンタイプ重油焚バーナ外観図（1）

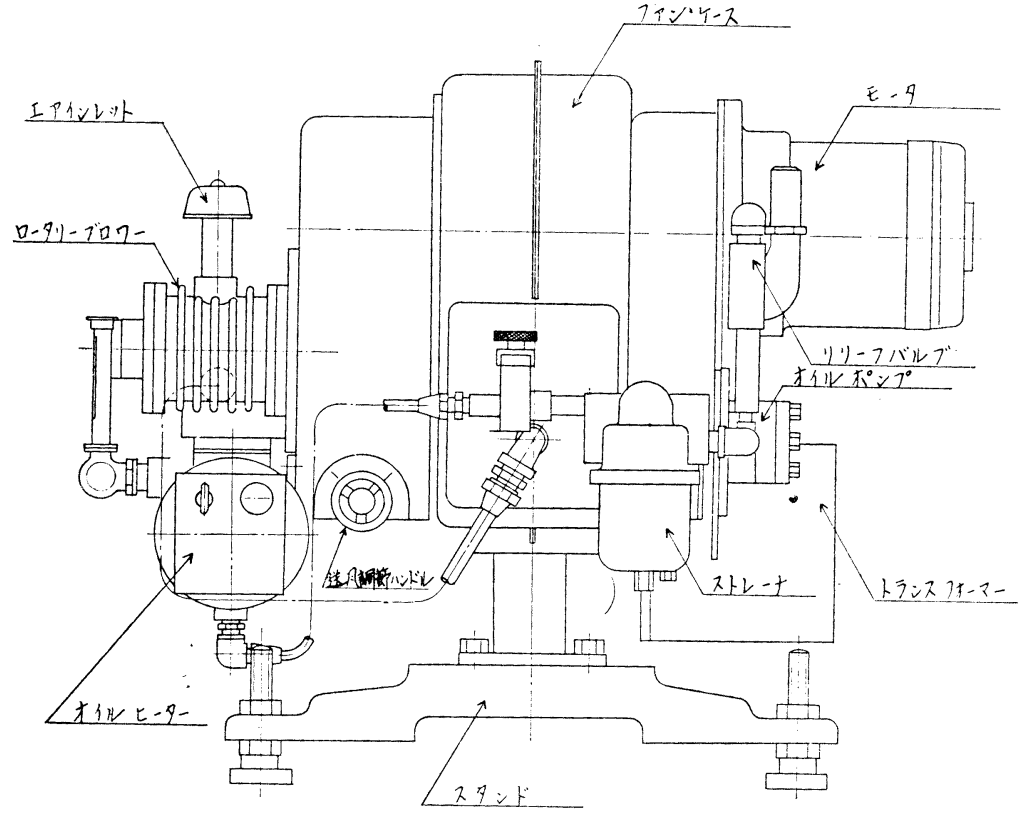

第 8 図 ガンタイプ重油焚バーナ外観図 (2)
品にこの種のものが見られる程 度で国産ではまだ完成されたも のがなかったが極く最近になっ て我々の研究が実って目的に合 致するものが出来るようになっ たのでこれを紹介したいと思う。 第 6 図に新しいB重油焚きガン タイプバーナの系統図を示す。 また第 $7 ， 8$ 図はその外観図を 示す。

パーナはモータ一軸に燃焼空 気用送風機が直結されその軸か らVベルトによりオイルポンプ 执よび霧化用ロータリブロワー が減速駆動される構造である。

然料はまずオイルポンプで吸 込まれ加圧されて, リリーフバ ルブで $1 \mathrm{~kg} / \mathrm{cm}^{2}$ の圧力に調整 されつつオイルストレーナを通 り，油量調整弁で油量を定めら バーナは形が小さく構造も簡単且值段も廉いので多く使 れオイルヒータに送られる。オイルヒーターでは約 70 ${ }^{\circ} \mathrm{C}$ 温度に加熱され, 三方口電磁弁を通り霧化用ブロワ 一の中に入り霧化用一次究気と混合しつつ送油管を通り バーナノズルに至りここから炉内に旋回噴出され, 微細 な嘪霧となる。着火は電気着火で本体の側面にある変圧 
器で $15,000 \mathrm{~V}$ に㫒圧したものをノズル先端のエレクト ロードで放電し噴霧に着火させる。燃焼用空気は本体付 属のシロッコファンによる。

オイルポンプは内接歯車式とし小形で強力なぬのを使 用している。油量調整弁は最燃焼量から最大量なでを容 易に調節出来るようになっており, またオイルプレヒー ターはオイルの最高予熱温度括よび許容温度差を適宜調 節できる温度調節器をそなえていて油温が一定温度に達 しないらちはバーナにスイッチが入らないよににインタ ーロック式になっている。これはB重油を電気着火する 場合万が一の不着火等を打こさせないための安全装置と なる。

三力口電磁弁はパーナの燃焼時のみ重油をプレヒータ 一からロータリーブロワーに拈くり, バー+停止時, プ レパージの時, ポストパージの時にはオイルをオイルラ インに戻すために設けられたものである。一次空気用口 一タリーブロワーの最高圧力は $0.5 \mathrm{~kg} / \mathrm{cm}^{2}$ である二 次空気用ドラフトチューブは二重管式送風管で内管では 噴射重油と旋回方向を逆にして送風し，外管では更に真 直方向に風を扣くって油と空気をよく混合し完全な燃焼 を行なわしめるよ5にしている。霧化用, ズルの設計に は特に留意した。第 9 図に重油楚ガンタイプー゚ーナの外 観を写真で示した。

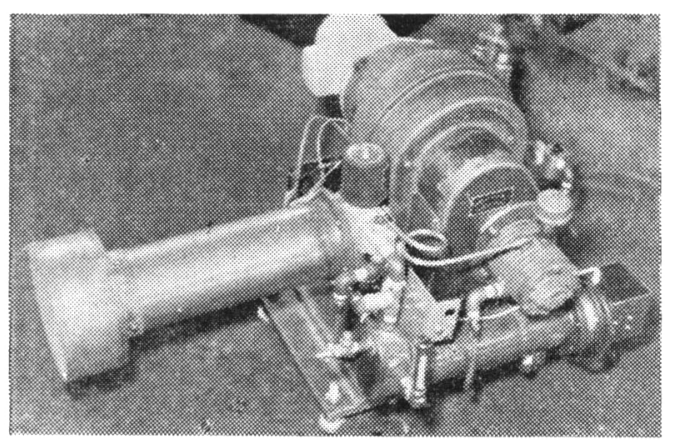

第 9 図重油楚ガンタイプバーナ

このバーナの自動制御法は光電管プロテリトシレーに よるオン・オフ操作または比例制御法荤採用している。 光電管プロテクトリレーはハニウェル製の $890 \mathrm{E} 上 \mathrm{C}-$ 7010 Aを併用した。
自動運転スイッチを投入すると着火スパークが開始さ れバーナモーターが始動してオイルポンプ, ロータリー ブロワーが運転をはじめ送油管，ノズル内和よび燃焼室 内のプレパージを始める。次に電磁弁の遅れタイマーか゚ 作動し約 5 秒の後弁が働きオイルがブロワーを通ってノ ズルを経て噴射着火される。重油に着火すると光電管は これを検出しプロテクトリレーに伝達し正常運転に入る。 若しスタート時不着火の場合は安全回路が働いてバー ナは自動停止する。この場合プロテクトリレーを手動で リセットする迄再スタートはしない。

バーナ停止の際は三方口電磁弁はオフとなり燃焼は終 り送油は停るがポストパージタイマーの作動で約 70 秒 間はバーナモーターが運転を継続し, 油系統部を清掃し てくれる。

このパーナの性能は次の通りである。

\begin{tabular}{|c|c|c|}
\hline 式 & O B -10 & O B -25 \\
\hline 油 & $10 \sim 38 l / h$ & $20 \sim 90 \mathrm{l} / \mathrm{h}$ \\
\hline- & $200 \mathrm{~V} \times 400 \mathrm{~W}$ & $200 \mathrm{~V} \times 750 \mathrm{~W}$ \\
\hline イグニショントランス & $200 \sim 15000 \mathrm{~V}$ & $200 \sim 15000 \mathrm{~V}$ \\
\hline オイルプレヒーター & $1.2 \mathrm{~kW}$ & $3 \mathrm{~kW}$ \\
\hline 三方 口電 磁 弁 & $30 \mathrm{~W}$ & $30 \mathrm{~W}$ \\
\hline
\end{tabular}

\section{$N$ 結 言}

以上新らしい燃焼設備の概要を述べたが紙数の都合で その詳細にわたることのできなかったことは遺感である。 最近のボイラは燃焼室ドラフトをこれまでの負圧 $2 \sim 3$ $\mathrm{m} / \mathrm{m}$ 水柱から正压 $50 \mathrm{~m} / \mathrm{m}, 60 \mathrm{~m} / \mathrm{m}$ あるいはそれ以上 でごく最近は $100 \mathrm{~m} / \mathrm{m}$ 以上に達するものができて来て いる。従って燃焼は加压然焼を行うことになり，パーナ もこれに適するように種々改良が加えられつつある。こ の方式によればボイラも同容量に対して小形となり, 火 炉熱負荷もこれまでの $350,000 \mathrm{kcal} / \mathrm{m}^{3} \mathrm{~h}$ 程度からその 2 倍近くまで向上している。この傾向は今後更に強くな ると思われるので, 燃焙機メ一カーもこの点を重要視し, 更に一層改善に留意して新らしいボイラに適応出来るも のをつくらなければならない。 